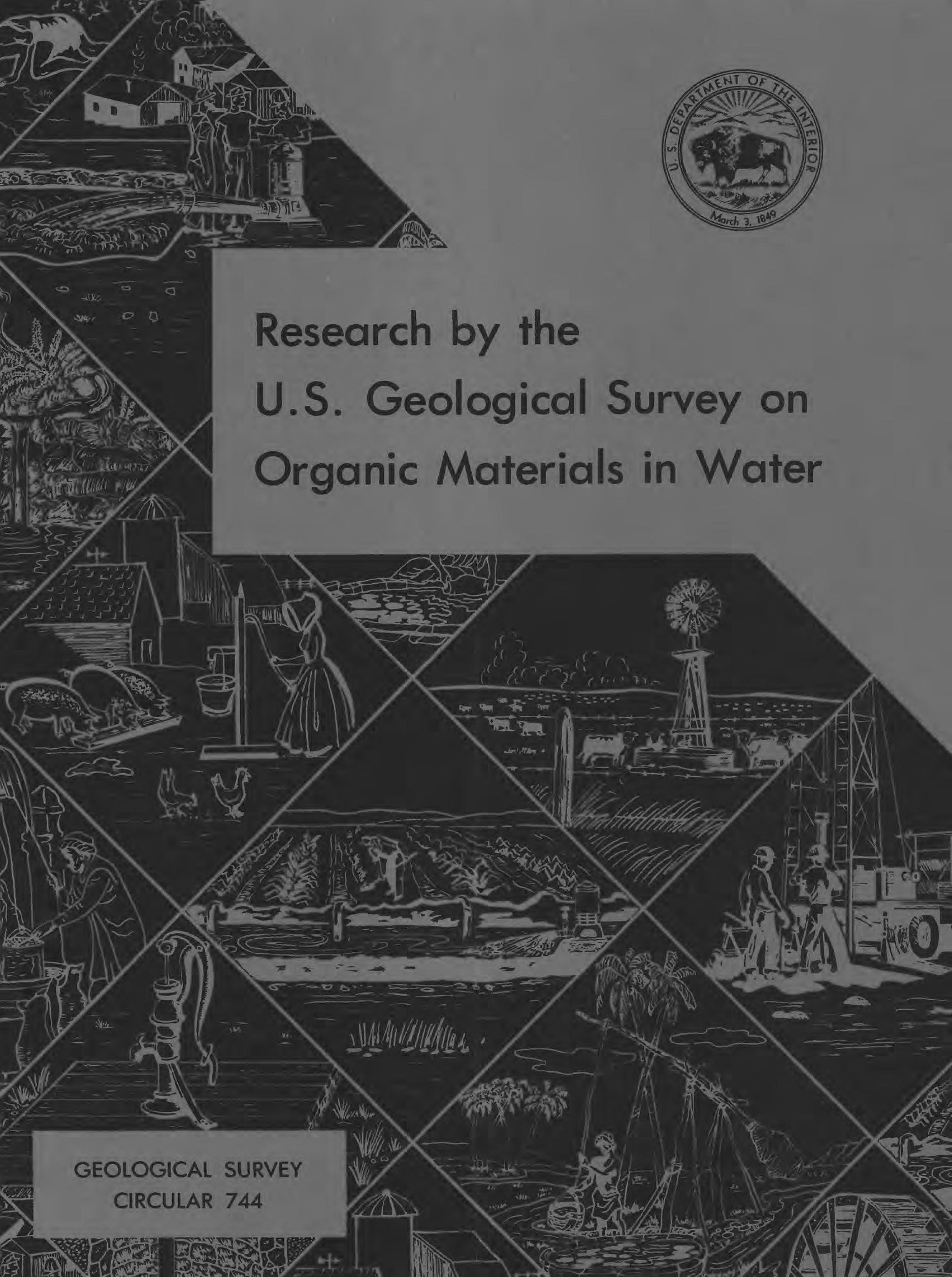


Research by the

U.S. Geological Survey on

Organic Materials in Water

By Robert A. Baker

GEOLOGICAL SURVEY CIRCULAR 744

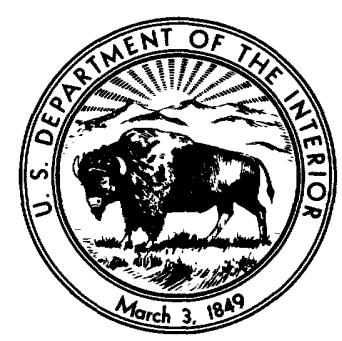




\section{United States Department of the Interior \\ THOMAS S. KLEPPE, Secretary}

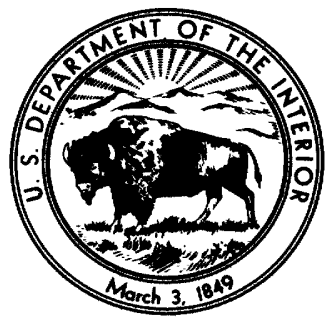

\section{Geological Survey}

V. E. McKelvey, Director

\section{Library of Congress Cataloging in Publication Data}

Baker, Robert Andrew, 1925-

Research by the U.S. Geological Survey on organic materials in water.

(Geological Survey Circular 744)

Bibliography: $p$.

Supt. of Docs. No.: 1 19.4/2:744

1. Water-Analysis-Research. 2. Organic water pollutants-Research. 3. Chemistry, Organic-Research. 4. United States Geological Survey.

I. Title. II. Series: United States Geological Survey Circular 744.

QE75.C5 No. 744 [GB658.7] 557.3'08s [628.1'61] 76-608296 


\section{CONTENTS}

Page

Abstract

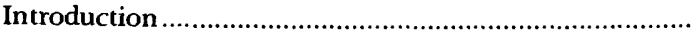

Analytical developments.

Dissolved organic carbon.

Pesticides....
1

1

2
Humic acids...........

Field studies ........................................................... 4

Long-range plans........................................................... $\quad \mathbf{5}$

References cited ....................................................... 


\title{
Research by the U.S. Geological Survey on Organic Materials in Water
}

\author{
By Robert A. Baker
}

\section{ABSTRACT}

The U.S. Geological Survey has responsibility for investigating the Nation's water resources for source, availability, quantity, and quality. This paper describes the Geological Survey's research on organic substances in water and fluvial sediments. Results and ongoing studies are examined. Typical research includes: Separation, concentration, and chromatographic identification of volatile acids; free-flow electrophoresis fractionation of natural organic materials; identification of chlorinated insecticides in suspended sediments and bottom materials; fate of organics following underground disposal; determination of humic and fulvic acid stability constants and characterizations; identification of low-molecular weight chloroorganic constituents in water; PCB (polychlorinated biphenyl compound) distribution in aquatic environments; dissolved organic carbon in ground water; and improvement in separation and concentration schemes prior to analyses.

\section{INTRODUCTION}

Evaluation of the organic and biological aspects of the Nation's water resources by the U.S. Geological Survey coincides with its initiation of research in these fields in the 1960's. By 1965 a pesticidemonitoring network was established. Increasingly, emphasis has been placed on elucidation of principles and relationships necessary for solution of practical problems associated with hydrology. Although the effort devoted to organic contaminants has been modest, considerable progress has been made, and noteworthy results have been achieved. A summary of prior and current research on this subject is presented.

\section{ANALYTICAL DEVELOPMENTS}

The following are representative of analytical developments made to support field investigations:

Analysis of formic and acetic acids in aqueous solution at relatively low concentrations had often presented a problem. A procedure combining steam distillation and concentration steps followed by flame-ionization detection, gas-liquid chromatography permitted determination of $1.0 \mathrm{mg} / 1$ and 0.03 $\mathrm{mg} / \mathrm{l}$, respectively, of formic and acetic acid (White and Leenheer, 1974).

Preparative free-flow electrophoresis was found to be an efficient method of conducting large-scale fractionations of natural organic polyelectrolytes occurring in many surface waters and solids. The method depends on mass and charge. A decreasing mass-charge ratio increases electrophoretic mobility. The method obviates the problem of adsorption upon a supporting medium. Application of the technique to natural samples, as well as associated sample-preparation techniques has been defined (Leenheer and Malcolm, 1973a). The free-flow electrophoresis procedure was applied to soluble river organic matter and soil fulvic acids. Significant quantities of virtually colorless organic material were found in soil and river preparations. Polysaccharides represent 20 to 75 percent of the colorless soil fulvic acids but only 3.2 to 7.0 percent of river preparations. Polysaccharides were greater in Northern than in Southern States. This suggested slower degradation in cooler climates (Leenheer and Malcolm, 1973b).

Analyses of coextratives during pesticide cleanup revealed presence of elemental sulfur. Elemental sulfur is often used as a fungicide and miticide and appears in hexane extracts. Gas chromatographic analysis of aldrin is particularly susceptible to interferences by elemental sulfur. A technique was developed to eliminate the interference by extraction on a small drop of elemental mercury (Goerlitz and Law, 1971).

Chlorinated napthalenes are produced for uses analogous to PCB's (polychlorinated biphenyl compounds). They are employed as engine oil additives, fabric dying, impregnation for automobile capacitors, electroplating stopoff compounds, and carbon electrode impregnation. They can interfere in pesticide residual analyses and are often even more difficult to detect on conventional electron-capture 
chromatography. Various methods of identifying chlorinated naphthalenes have been examined. Combined gas chromatograpy-mass spectrometry is the most effective detection procedure. The base peak is typically found in the molecular ion cluster, and spectra are unique (Goerlitz and Law, 1972).

Water and soil contamination by TNT and RDX is likely around munitions manufacturing sites. Methodology was developed for measuring the presence of these substances. Volatile solvent extraction is followed by removal of bulk solvent and separation from extraneous material by column adsorption chromatography. TNT and RDX are measured by electron-capture gas chromatography, using two columns of different retention characteristics. Minimum detectable concentrations are $\mathbf{0 . 0 0 5}$ $\mu \mathrm{g} / \mathrm{l}$ (Goerlitz and Law, 1975).

A novel system of classification, fractionation, and analysis of organic solutes in aqueous systems has been evolved from ongoing research (J. A. Leenheer, written commun., 1975). Attempts to characterize such solutes by iractionating the DOC (dissolved organic carbon) based on hydrophobic-hydrophilic nature and acid-base characteristics led to investigation of Rohm and Haas Amberlite XAD resins. ${ }^{1}$ The XAD-8 resin series was found to have high sorptive capacity for natural organic polyelectrolytes (humic and fulvic acids). Alkaline eluants were effective in quantitative desorption. Prior experience with other resins had led to irreversible sorption and resin fouling. The use of XAD-8 resin permitted development of analytical procedures which have since been applied to surface and ground waters.

Other ongoing investigations include: Application of lasar-Raman spectroscopy to remote sensing of water quality; characterization of organic constituents in domestic sewage effluents and their fate on distribution to surface and ground waters; characterization and fate of organic contaminants released from coal and shale residues; and quantification of organic substances in water and sediment from representative rivers, lakes, and ground waters.

\section{DISSOLVED ORGANIC CARBON}

Traditionally, semiquantitative measures of organic constituents of water have included BOD (biochemical oxygen demand) and COD (chemical oxygen demand). These measurements are being replaced by quantitative procedures including DOC and SOC (suspended organic carbon). The techni-

\footnotetext{
'The use of brand names in this report is for identification purposes only and does not imply endorsement by the U.S. Geological Survey
}

ques for DOC and SOC have been subjected to rigorous testing Malcolm and Leenheer, 1973). DOC and SOC are independent of microbial effects, toxic substances, and variability with diverse organic constituents. Inorganic interferences are readily isolated. Combining DOC and SOC provides a measure of TOC (total organic carbon). TOC is commonly measured as a single value by instrumental means. TOC values, so derived, commonly lack the precision and accuracy of combined DOC-SOC values.

DOC was shown to provide definitive information regarding the level and areal extent of ground-water contamination in Mojave River sediments near Barstow, Calif. (Hughes and others, 1974). The underlying alluvial aquifer has been degraded by industrial and municipal wastes. Concomitantly, DOC values have increased from 0.1 to 6 or $7 \mathrm{mg} / \mathrm{l}$ in the ground water. The technique serves as a tracer of discharge patterns. Two plumes of degraded water were shown to exist at different depths. Areal distribution suggests selective adsorption of some constituents by the aquifer sediments.

A survey of DOC in ground water was made at 100 sites in 27 States. Samples were pressure filtered at the time of collection and immediately frozen on dry ice. Subsequent analyses showed DOC to vary from less than the $0.1 \mathrm{mg} / \mathrm{l}$ detection limit to $15 \mathrm{mg} / \mathrm{l}$. The DOC values were correlated with various chemical and geological properties (Leenheer and others, 1974).

Six rivers, the Missouri, Neuse (N.C.), Ohio, Brazos (Tex.), Mississippi, and Sopchoppy (Fla.), were monitored for organic loading (Malcolm and Durum, 1976). Annual organic loads of 3.4 billion kilograms and 47 million kilograms of the Mississippi and Brazos Rivers, respectively, were approximately equally distributed between dissolved and suspended phases. The Missouri load of 725 million kilograms was chiefly in the suspended phase. However, the 6.4 and 19 million kilograms loads of the Sopchoppy and Neuse Rivers, respectively, were chiefly in the dissolved phase. In most rivers DOC concentrations were usually less than $8 \mathrm{mg} / \mathrm{l}$. SOC concen trations varied widely with discharge, ranging between 1 and 14 weight-percent. Except for the Mississippi and Sopchoppy Rivers, DOC and SOC fluctuated with the seasons. The sediment phase carbon:nitrogen ratio of all these systems averaged less than $8: 1$ as compared with 12: 1, or more, for most soils. This indicates nitrogen enrichment of stream sediment. 


\section{PESTICIDES}

The distribution of pesticides and their decomposition products in the Nation's water systems has been of continuing concern. A national monitoring program has been in operation (Feltz and others, 1971). Emphasis was on 20 selected stations in the Western United States in 1968. There were 153 stations operating coast-to-coast in May 1975. The analytical laboratories have devoted continuing effort to improvement of sampling, preservation, and handling of samples containing pesticides. Cooperative studies have been conducted with other governmental units and inhouse research has addressed specific needs. The following cases typify past investigations.

Organochlorine insecticides were monitored in the Everglades of south Florida. DDT and its metabolites DDD and DDE in the range 0.00-0.03 $\mu \mathrm{g} / \mathrm{l}$ were found in water. Underlying marshy soil contained up to threefold greater concentrations. Similarly increased levels were found in algal mats, omniverous crustaceans, and fishes. It was postulated that these organochlorine substances were introduced by water inflow and aerial transport (Kolipinski and others, 1971).

Pesticide monitoring of the streams of Western States has been a continuing effort (Brown and Nishioka, 1967; Manigold and Schulze, 1969; Schulze and others, 1973). From 1968 to 1971 DDT was the most frequently occurring insecticide, and 2-, 4-, 5-T, the most common herbicide. Concentrations were highest in samples containing larger concentrations of suspended sediments. Beginning in July 1970 parathion, methylparathion, malathion, and diazinon were measured monthly at 20 stations.

Sediment and bottom material represent the transport mode and repository of many organic contaminants including pesticides. Procedures have been developed and standardized for pesticide extraction and analysis (Goerlitz and Law, 1974a). Acetonehexane extraction is followed by adsorption chromatography to isolate the coextractants, polychlorinated biphenyls and polychlorinated napthalenes. Sulfur is removed by precipitation.

San Francisco Bay is a principal aquatic resource in California. Millions of persons depend on its waters for multiple uses. The bay receives waters from many tributaries. Bottom materials from 26 streams tributary to the bay were analyzed for pesticides. DDD, DDE, DDT, and PCB residues were present in most samples. Chlordane proved equally ubiquitous. One stream sample contained polychlorinated napthalene residues. Combined gas chromatography-mass spectrometry was used to identify compounds occurring in concentrations greater than $20 \mu \mathrm{g} / \mathrm{kg}$ (Law and Goerlitz, 1974). These same investigators demonstrated that it is essential to consider all particle-size fractions in bottom-sediment analysis if quantitative results are to be obtained (Goerlitz and Law, 1974b).

Interfering materials often pose a problem in gasliquid chromatographic analyses of pesticide residues. Rapid and economical cleanup procedures for treating samples are necessary. Various adsorbents and solvent systems were tested using many pesticides (Law and Goerlitz, 1970). Microcleanup column techniques were devised for use with surface- and ground-water samples. These techniques have been in regular use for many years.

\section{HUMIC ACIDS}

Humic and fulvic acid components of soils, sediments, and natural waters are involved in physical, biological, and chemical processes affecting water quality. It has long been known that these abundant substances are mixtures of chemically different molecular species. However, separation and elucidation of the complex mixtures have proved to be difficult. Humic acids are characteristically aromatic in nature and contain phenolic, quinone, and acidic groups. Amine and alcohol groups and ether linkages are also present. It will be necessary to define these substances if their role in water quality is to be properly assessed.

A research project is devoted to investigating these complex natural substances. Their isolation, properties, and reaction mechanisms with other constituents of natural aqueous systems are being defined. Adsorption chromatography on Sephadex gel has been applied to humic acid salts. The humics were extracted from: (1) A North Carolina sandy soil of low clay and approximately 0.2-percent organic carbon; (2) a Florida sandy soil; (3) a New Mexico alpine bog, high in decaying organic material; (4) a Washington organic soil made up of peat and undifferentiated alluvial soil containing decaying organic matter, sand, and clay; and (5) an Alamosa ground water from a zone $60-120 \mathrm{~m}$ beneath the surface and highly colored from peat bed contact. Fractionation of the sodium salts is attributed principally to adsorption, but molecular sieving and ion exchange are also taking place (Wershaw and Pinckney, 1973a). 
The aforementioned fractionation of the humic acids was by adsorption chromatography on Sephadex G-50 followed by chromatography on either a $\mathrm{G}-25$ or a $\mathrm{G}-100$ column. The fractions of the solutions were then examined by small-angle $\mathrm{X}$ ray scattering. Three types of aggregation behavior were identified: (1) Some fractions show little change in aggregation above $\mathrm{pH} 3.5$; (2) one fraction aggregates at $\mathrm{pH}$ values higher and lower than 7 but is completely disassociated at 7; and (3) some fractions show decreased aggregation with increasing $\mathrm{pH}$. Some large particles still persist, however, at $\mathrm{pH}$ 11.5. Differences in association tendency are attributed to interaction of varying attractive and repulsive forces. The multiplicity of active forces in humic systems includes hydrogen-bonding, $\pi$ bonding between planar aromatic moieties, and other coulombic interactions (Wershaw and Pinckney, 1973b).

Although there have been other contributions emanating from this project, the most promising breakthrough involves recent analytical advances. Previous research could not fully utilize such systems as mass spectroscopy because of limited volatility. A new procedure has been developed in which humicacid fractions are dissolved in pyrrolidone and methylated with diazomethane. Groups not amenable to these steps are derivatized by other means. The resulting derivatives are yielding useful chemical structural characterizations.

\section{FIELD STUDIES}

Although many analytical procedures and basic investigations related to organics are conducted in the research laboratory, a conscious effort is made to extrapolate advances to field application. Technology transfer is accomplished in a variety of ways. These include formal classwork, on-site demonstrations by researchers in field situations, and cooperative studies with others in public and private sectors. The following field studies typify the problems under investigation:

CEC (cation exchange capacity) of sediments can affect stream water quality. In turn, the parent material, age of weathering surface, climatic factors, degree of weathering, and dispersion affect CEC. Decreasing particle size usually produces an increase in CEC. A field study demonstrated these principles and the effect of organic loading. Sediment from the Mattole River was classified in particle sizes ranging from less than $0.2 \mu \mathrm{m}$ up to fine gravel (4-9.5 mm).
Carbon content was greatest for the finest particulates, 2.58 percent for the aforementioned finest clays. Lowest carbon content of 0.3 percent was in the gravel-size particulates. CEC was greater for particles associated with organic matter and ranged from approximately $50 \mathrm{meq} / 100 \mathrm{~g}$ at $0.1 \mu \mathrm{m}$ to approximately $10 \mathrm{meq} / 100 \mathrm{~g}$ at $10 \mu \mathrm{m}$. The exchange process is very fast. Equilibration of the solids with surrounding liquid is rapid (Malcolm and Kennedy, 1970).

PCB's have been established as universally distributed in the environment as a result of industrial applications. The extent of their effect, especially in aquatic systems, is under intensive study. PCB residues have been analyzed by multiple-pesticide residue methods for water, suspended sediment, and bottom material (Goerlitz and Brown, 1972). Residues have been detected in samples from 19 States throughout the Nation. Unfiltered water concentrations ranged from 0.1 to $4.0 \mu \mathrm{g} / 1$ while bottom sediment concentrations varied from 5.0 to $3200 \mu \mathrm{g} / \mathrm{kg}$. This ongoing survey is intended to define the distribution of PCB's in major drainage basins of the United States (Crump-Wiesner and others, 1973). During the course of this study, the presence of significant concentration levels of PCN's was detected in water and sediment samples collected from a south Florida drainage ditch. The sediment samples collected from a south Florida drainage ditch. The sediment samples contained a mixture of PCN's varying from 1,250 to $5,000 \mu \mathrm{g} / \mathrm{kg}$, and the water samples averaged $5.7 \mu \mathrm{g} / \mathrm{kg}$. Identification was confirmed by microcoulometry and GC-MS.

Increasingly underground disposal of wastes is being practiced. The effects are not always readily evident. A study was made in North Carolina at a location where 380 to $760 \mathrm{l} / \mathrm{min}$ of industrial organic wastes were pumped at 10 atm into multiple permeable zones 259 to $305 \mathrm{~m}$ below the surface. The zones consisted of a sand, gravel, and limestone aquifer of Late Cretaceous age. Before injection, the waste was adjusted by lime to $\mathrm{pH} 4$. The disposal was not entirely satisfactory. Wells plugged, and waste leakage occurred into shallower aquifers. The wastes proved geochemically reactive. These contained $7100 \mathrm{mg} / \mathrm{l}$ DOC. The major organic constituents in order of decreasing abundance were acetic acid, formic acid, p-toluic acid, formaldehyde, methanol, terephthalic acid, phthalic acid, and benzoic acid. Movement of the waste front was monitored by observation wells. Methane-rich gas evolved. Ferrous iron, hydrogen sulfide, and sulfide pre- 
cipitates indicated biochemical reductive processes. Organism counts increased to $10^{6} / \mathrm{ml}$ at the waste front. These were chiefly anaerobic, methanogenic bacteria. Concurrent laboratory studies supported the field studies. A conceptive model, detailing waste reactivity and movement in the subsurface from injection point to waste front, was developed (Leenheer and Malcolm, 1973c; Leenheer, Malcolm, and White, 1976).

The in situ clay mineral dissolution by the aforementioned waste injection has been analyzed (Malcolm, Leenheer, and Weed, 1975). The mechanism was postulated to entail organic acid sorption on mineral surfaces, complexation of metals by organic ligands, and desorption of the ligand-metal complex.

\section{LONG-RANGE PLANS}

Research and supporting analytical programs must be subjected to constant reevaluation to assure that they are responsive to priority needs. Subjects related to organics in water that currently merit priority consideration include:

Improvement in analytical methodology for trace organic sampling, preservation, transfer, and analyses in salt and brackish waters.

Development of detailed information on microorganic transport and fate at specific sites for sensitivity testing of mathematical models.

Elucidation of metallo-organic interactions in natural and man-stressed aqueous systems.

Clarification of the effect of condensation nuclei, such as clay particulates, on organic transport. (Sedimentation determines the ultimate benthic concentration and transportation of hydrophobic constituents, such as pesticides and herbicides.)

Investigation of bioaccumulation of heavy metals and potentially carcinogenic trace organics and the role of such processes in altering water quality.

Determination of the nature and effect of trace organic contaminants in urban runoff under varying climatic, topographic, and land-use conditions.

Monitoring the stress on surface and ground waters from nonpoint sources of trace organics. (Landfill, land-surface disposal, and deep-well waste injection are typical concerns.)

Improvement of organic sensors to be used in conjunction with automatic data collection platforms and data relay systems for remote, continuous monitoring of water quality.
Even this limited list poses challenges. Manpower and facility limitations preclude intensive research on all these subjects. However, these needs will have to be addressed if water resources demands are to match expansion of international requirements for food, fiber, and energy. Research on organics by the U.S. Geological Survey is expected to be an increasingly important aspect in the elucidation of the hydrologic system over the next decade.

\section{REFERENCES CITED}

Brown, Eugene, and Nishioka, Y. A., 1967, Pesticides in selected western streams-A contribution to the national program: Pesticides Monitoring Jour., v. 1, no. 2, p. 38-46.

Crump-Wiesner, Hans J., Feltz, H. R., and Yates, M. L., 1973, A study of the distribution of polychlorinated biphenyls in the aquatic environment: U.S. Geol. Survey Jour. Research, v. 1, no. 5, p. 603-607.

Feltz, H. R., Sayers, W. T., and Nicholson, H. P., 1971, National monitoring program for the assessment of pesticide residues in water: Pesticides Monitoring Jour., v. 5, no. 1, p. 54-62.

Goerlitz, D. F., and Brown, Eugene, 1972, Methods for analysis of organic substances in water: U.S. Geol. Survey Techniques Water-Resources Inv., book 5, chap. 5-A3, 40 p.

Goerlitz, D. F., and Law, L. M., 1971, Note on removal of sulfur interferences from sediment extracts for pesticide analysis: Bull. Environmental Contamination and Toxicology, v. 6 , no. 1, p. 9-10.

1972, Chlorinated naphthalenes in pesticide analysis: Bull. Environmental Contamination and Toxicology, v. 7, no. 4 , p. $243-251$

1974a, Determination of chlorinated insecticides in suspended sediment and bottom material: Jour. Assoc. Official Anal. Chemists, v. 57 , no. 1 , p. 176-181

$1974 \mathrm{~b}$, Distribution of chlorinated hydrocarbons in stream bottom materiak: U.S. Geol. Survey Jour. Research, v. 2 , no. 5 , p. $541-543$.

1975, Gas chromatographic method for the analysis of TNT and RDX explosives contaminating water and soilcore material: U.S. Geol. Survey Open-File Rept. 75-182.

Hughes, J. L., Eccles, L. A., and Malcolm, R. L., 1974, Dissolved organic carbon (DOC), an index of organic contamination in ground water near Barstow, California: Ground Water Jour., v. 12, no. 5, p. 283-290.

Kolipinski, M. C., Higer, A. L., and Yates, M. L., 1971, Distribution of chlorinated hydrocarbons in stream-bottom material: Pesticides Monitoring Jour., v. 5, no. 3, p. 281-288.

Law, L. M., and Goerlitz, D. F., 1970, Microcolumn chromatographic cleanup for the analysis of pesticides in water: Jour. Assoc. Official Anal. Chemists, v. 53, no. 6, p. 12761286.

1974, Selected chlorinated hydrocarbons in bottom material from streams tributary to San Francisco Bay, 1974: Pesticides Monitoring Jour., v. 8, no. 1, p. 33-36.

Leenheer, J. A., and Malcolm, R. L., 1973a, Preparative freeflow electrophoresis and a method of fractionation of natural organic materials: U.S. Geol. Survey Water-Supply Paper 1817-D, 14 p. 
1973b, Fractionation and characterization of natural organic matter from certain rivers and soils by free-flow electrophoresis: U.S. Geol. Survey Water-Supply Paper 1817-E, 14 p.

1973c, Chemical and microbial transformations of an industrial organic waste during subsurface injections: Proc. Inst. Environmental Sci., Anaheim, Calif., Apr. 1-3, 1973, p. 351-360.

Leenheer, J. A., Malcolm, R. L., McKinley, P. W., and Eccles, L. A., 1974, Occurrence of dissolved organic carbon in selected ground-water samples in the United States: U.S. Geol. Survey Jour. Research, v. 2, no. 3, p. 361-369.

Leenheer, J. A., Malcolm, R. L., and White, W. R., 1976, Investigations of the reactivity and fate of certain organic components of an industrial waste after deep-well injection: Environmental Sci. and Technology. (In press.)

Malcolm, R. L., and Durum, W. H., 1976, Organic carbon and nitrogen concentrations and annual organic carbon load of six selected rivers of the United States: U.S. Geol. Survey Water-Supply Paper 1817-F, 21 p.

Malcolm, R. L., and Kennedy, V. C., 1970, Variation of cation exchange capacity and rate with particle size in stream sediment: Jour. Water Pollution Control Federation, v. 42, no. 5, pt. 2, p. R153-R159.
Malcolm, R. L., and Leenheer, J. A., 1973, The usefulness of organic carbon parameters in water quality investigations: Anaheim, Calif., Inst. Environmental Sci., Proc. No. 19, p. 336-340.

Malcolm, R. L., Leenheer, J. A., and Weed, S. B., 1975, Dissolution of aquifer clay minerals during deep-well disposal of industrial organic waste: Mexico City, Proc. Internat. Clay Conf., p. 477-494.

Manigold, D. B., and Schulze, J. A., 1969, Pesticides in selected western streams-A progress report: Pesticides Monitoring Jour., v. 3 no. 2, p. 124-135.

Schulze, J. A., Manigold, D. B., and Andrews, F. L., 1973, Pesticides Monitoring Jour., v. 7, no. 1, p. 73-84.

Wershaw, R. L., and Pinckney, D. J., 1973a, The fractionation of humic acids from natural water systems: U.S. Geol. Survey Jour. Research, v. 1, no. 3, p. 361-366.

1973b, Determination of the association and dissociation of humic acid fractions by small x-ray scattering: U.S. Geol. Survey Jour. Research, v. 1, no. 6, p. 701-707.

White, W. R., and Leenheer, J. A., 1974, Determination of free formic and acetic acids by gas chromatography using the falme ionization detector: Jour. Chromatographic Sci. (In press.) 